\title{
REVIEW
}

\section{Apoptosis in myocardial ischaemia and infarction}

\section{P A J Krijnen, R Niimeijer, C J L M Meijer, C A Visser, C E Hack, H W M Niessen}

J Clin Pathol 2002;55:801-811

Recent studies indicate that, in addition to necrosis, apoptosis also plays a role in the process of tissue damage after myocardial infarction, which has pathological and therapeutic implications. This review article will discuss studies in which the role and mechanisms of apoptosis in myocardial infarction were analysed in vivo and in vitro in humans and in animals.

See end of article for authors' affiliations

.......................

Dr P A J Krijnen, Department of Pathology, VU University Medical Centre, Room nr. OE 16, De Boelelaan 1117, PO Box 7075, 1007MB

Amsterdam, The

Netherlands:

paj.krijnen@vumc.nl

Accepted for publication 9 May 2002
T he common view on how cardiomyocytes die during or after myocardial infarction has altered in recent years. For a long time necrosis was regarded as the sole cause of cell death in myocardial infarction. Now, recent studies indicate that apoptosis also plays a role in the process of tissue damage subsequent to myocardial infarction. Although both necrosis and apoptosis result in the death of the cell, they differ in several morphological and cellular regulatory features.

Necrosis is characterised by the rapid loss of cellular homeostasis, rapid swelling as a result of the accumulation of water and electrolytes, early plasma membrane rupture, and the disruption of cellular organelles. As a result of the membrane rupture and subsequent leakage of a broad array of cellular material, necrosis induces an inflammatory response. ${ }^{1-3}$

Apoptosis or programmed cell death is, unlike necrosis, a highly regulated and energy requiring process. Apoptosis is characterised by shrinkage of the cell and the nucleus. The nuclear chromatin is condensed into sharply delineated masses, and eventually breaks up. The cell then detaches from the surrounding tissue. At this stage, extensions bud out from its membrane, which eventually seal off to form membrane enclosed vesicles, called apoptotic bodies, containing condensed cellular organelles and nuclear fragments. These apoptotic bodies are either rapidly phagocytosed by neighbouring cells or undergo degradation, which resembles necrosis in a process called secondary necrosis. However, apoptosis is generally considered not to trigger an inflammatory response. $^{4}$

\section{"Although both necrosis and apoptosis result in the death of the cell, they differ in several morphological and cellular regulatory features"}

However, recently there has been much debate concerning which morphological features accurately reflect apoptosis. Furthermore, it has been suggested that the process of apoptosis is regulated by a large variety of different cellular mechanisms. Therefore, Sloviter suggested that perhaps the terms necrosis and apoptosis should be redefined as "passive cell death" and "active cell death", respectively.

The fact that apoptosis plays a role in the tissue damage seen after myocardial infarction has pathological and therapeutic implications. Because apoptosis is a highly regulated process, a better understanding of the circumstances that specifically trigger apoptosis during and after myocardial infarction, and a better understanding of the cellular mechanisms that control apoptosis, could lead to therapeutic strategies to limit the amount of tissue damage in patients with myocardial infarction.

In this review article, we will discuss studies in which the role of apoptosis in myocardial infarction was analysed in vivo and in vitro. In these studies, apoptotic cells were detected using the terminal deoxynucleotidyl transferase mediated dUTP nick end labelling method (TUNEL) combined with agarose gel DNA laddering, unless stated otherwise.

\section{STUDIES IN HUMANS}

\section{Apoptosis in human cardiomyocytes after} myocardial infarction

Studies in the ventricular myocytes of the hearts of patients who died of acute myocardial infarction (AMI) have shown that apoptosis plays a role in the process of cell death of cardiomyocytes. Saraste et al showed, in myocardial samples obtained from patients who died of acute AMI, that in addition to overt necrosis, a subset of myocytes undergoes apoptosis during ischaemia/ reperfusion injury ${ }^{6}$ (table 1 ). The apoptotic myocytes were most prominent in the border zones of recent infarction, ${ }^{6-9}$ whereas very few apoptotic cells were present in the remote non-infarcted myocardium. ${ }^{6}$ In line with this, increased uptake of Tc-99m labelled annexin $\mathrm{V}$ in the infarcted area, but not outside the infarcted

Abbreviations: Akt, protein kinase $B$; $A M I$, acute myocardial infarction; ERK, extracellular signal related kinase; ESCM, embryonic stem cell derived cardiomyocytes; HGF, hepatocyte growth factor; HSP, heat shock protein; ICE, interleukin $1 \beta$ converting enzyme; IGF-I, insulin-like growth factor I; JAK, Janus kinase; JNK, Jun $\mathrm{N}$-terminal kinase; MAPK, mitogen activated protein kinase; MEKK 1, MAPK kinase kinase; MI, myocardial infarction; $N F \kappa B$, nuclear factor $\kappa B ; N O$, nitric oxide; PARP, poly(ADP-ribose) polymerase; PI3 kinase, phosphatidylinositol 3'-kinase; SAPK, stress activated protein kinase; STAT, signal transducer and activator of transcription; TGF- $\beta 1$, transforming growth factor $\beta 1$; TNF, tumour necrosis factor; TUNEL, terminal deoxynucleotidyl transferase mediated dUTP nick end labelling 


\begin{tabular}{|c|c|c|c|c|}
\hline Model & $\begin{array}{l}\text { Prevalence of } \\
\text { apoptosis }\end{array}$ & Source & Timing of apoptosis & Marker of apoptosis used \\
\hline \multirow[t]{3}{*}{ Human } & Yes & Human & 6-120 h after AMI & TUNEL + DNA laddering 6 \\
\hline & Yes & Human & 3-14 h after AMI & TUNEL + DNA laddering ${ }^{8}$ \\
\hline & Yes & Human & $3.5-22 \mathrm{~h}$ after AMl & Annexin $\mathrm{V}^{11}$ \\
\hline \multirow[t]{19}{*}{ In vivo animal } & Yes & Rat & $2 \mathrm{~h}$ to $7 \mathrm{~d}$ & TUNEL + Ab myosin heary chain ${ }^{12}$ \\
\hline & Yes & Rat & $2.25 \mathrm{hl}$ & TUNEL ISEL + DNA laddering ${ }^{13}$ \\
\hline & Yes & Rat & $45 \mathrm{~min} \mathrm{I}$ and $1 \mathrm{~h} \mathrm{R}$ & TUNEL ISEL + DNA laddering ${ }^{14}$ \\
\hline & Yes & Rat & $24 \mathrm{~h}$ to $12 \mathrm{w}$ & TUNEL ${ }^{14}$ \\
\hline & No & Dog & $7 \mathrm{hl}$ & TUNEL + DNA laddering ${ }^{15}$ \\
\hline & Yes & Dog & $6 \mathrm{~h} \mathrm{I}$ and $6 \mathrm{~h} \mathrm{R}$ & TUNEL + DNA laddering ${ }^{15}$ \\
\hline & Yes & Rat & $3 \mathrm{~h} \mathrm{I}$ & TUNEL + DNA laddering ${ }^{16}$ \\
\hline & Yes & Rabbit & $30 \mathrm{~min}$ and $4 \mathrm{~h} \mathrm{R}$ & TUNEL + DNA laddering ${ }^{17}$ \\
\hline & No & Rat & $10 \mathrm{~min} \mathrm{I}$ and $3 \mathrm{~h} \mathrm{R}$ & TUNEL + sandwich enzyme assay ${ }^{18}$ \\
\hline & Yes & Rat & $20 \mathrm{~min} I$ and $3 \mathrm{~h} \mathrm{R}$ & TUNEL + sandwich enzyme assay ${ }^{18}$ \\
\hline & Yes & Dog & $30 \mathrm{~min} \mathrm{I} \mathrm{and} 3 \mathrm{~h} \mathrm{R}$ & DNA laddering 19 \\
\hline & Yes & Rat & $30 \mathrm{~min} I$ and $3 \mathrm{~h} \mathrm{R}$ & TUNEL + DNA laddering ${ }^{20}$ \\
\hline & Yes & Rat & $30 \mathrm{~min} \mathrm{I} \mathrm{and} 3 \mathrm{~h} \mathrm{R}$ & Elisa and westernblot ${ }^{21}$ \\
\hline & Yes & Rat & $30 \mathrm{~min} I$ and $6 \mathrm{~h} \mathrm{R}$ & TUNEL + DNA laddering ${ }^{22}$ \\
\hline & Yes & Mouse & $1 \mathrm{~h}-72 \mathrm{~h}$ & TUNEL + DNA laddering ${ }^{23}$ \\
\hline & Yes & Rat & until $24 \mathrm{~h}$ & TUNEL + DNA laddering ${ }^{24}$ \\
\hline & No & Rabbit & $4,5 \mathrm{~h} \mathrm{I}$ & TUNEL + DNA laddering ${ }^{25}$ \\
\hline & Yes & Rabbit & $30 \mathrm{~min} I$ and $4 \mathrm{~h} \mathrm{R}$ & TUNEL + DNA laddering ${ }^{25}$ \\
\hline & Yes & Mouse & $15 \mathrm{~min} I$ and $30 \mathrm{~min} R$ & Annexin $V$ and DNA laddering 26 \\
\hline \multirow[t]{6}{*}{ Isolated animal hearts } & Yes & Rat/Mouse & $25 \mathrm{~min} I$ and $4 \mathrm{~h} \mathrm{R}$ & TUNEL $^{27}$ \\
\hline & Yes & Rat & $30 \mathrm{~min} I$ and $2 \mathrm{~h} \mathrm{R}$ & TUNEL + DNA laddering ${ }^{28}$ \\
\hline & Yes & Rat & $30 \mathrm{~min} I$ and $2 \mathrm{~h} \mathrm{R}$ & TUNEL + DNA laddering ${ }^{29}$ \\
\hline & No & Rat & $60 \mathrm{~min} \mathrm{I}$ & TUNEL + Ab myosin heavy chain ${ }^{30}$ \\
\hline & Yes & Rat & $15 \mathrm{~min} I$ and $2 \mathrm{~h} \mathrm{R}$ & TUNEL + Ab myosin heavy chain ${ }^{30}$ \\
\hline & Yes & Rabbit & $30 \mathrm{~min} \mathrm{I}$ and $1 \mathrm{~h} \mathrm{R}$ & TUNEL + DNA laddering ${ }^{31}$ \\
\hline \multirow[t]{7}{*}{ Isolated cardiomyocytes } & Yes & Rat & $48 \mathrm{hl}$ & TUNEL + DNA laddering ${ }^{32}$ \\
\hline & Yes & Rat & $48 \mathrm{~h} \mathrm{I}$ and $3 \mathrm{~h} \mathrm{R}$ & TUNEL + DNA laddering ${ }^{32}$ \\
\hline & No & Rat & $18 \mathrm{~h} \mathrm{I}$ and $12 \mathrm{~h} \mathrm{R}$ & Annexin V/PI + TUNEL + DNA laddering ${ }^{33}$ \\
\hline & Yes & Rabbit & $30 \mathrm{~min} I$ and $24 \mathrm{~h} \mathrm{R}$ & TUNEL $^{34}$ \\
\hline & No & Rat & $3 \mathrm{hl}$ and $2 \mathrm{~h} \mathrm{R}$ & Annexin $\mathrm{V} / \mathrm{Pl}^{35}$ \\
\hline & No & Mouse & $24 \mathrm{hl}$ & DNA laddering ${ }^{36}$ \\
\hline & Yes & Mouse & $24 \mathrm{~h} \mathrm{I}$ and $8 \mathrm{~h} \mathrm{R}$ & DNA laddering ${ }^{36}$ \\
\hline
\end{tabular}

AMI, acute myocardial infarction; d, days; h, hours; I, ischaemia; min, minutes; PI, propidium iodide; R, reperfusion; TUNEL, terminal deoxynucleotidyl transferase mediated dUTP nick end labelling; w, weeks.

area in patients with AMI, suggests the occurrence of apoptosis in this area, ${ }^{6}$ although it should be noted that annexin $\mathrm{V}$ stains necrotic cells in addition to apoptotic cells. In contrast, other studies have shown a substantial amount of apoptosis in the "remote from ischaemia" areas also. ${ }^{810}$

\section{Bcl-2 and Bax}

As mentioned earlier, apoptosis is a highly regulated process in which several regulatory proteins play a part, and in which the balance between an array of regulatory proteins decides the fate of the cell. The expression of two such regulatory proteins, bcl-2 and Bax, has been studied in the hearts of patients who died of AMI. ${ }^{37} \mathrm{Bcl}-2$, an apoptosis inhibitor, is not expressed in non-infarcted myocardial tissue, ${ }^{38}$ but it is expressed in cardiomyocytes surrounding infarcted areas soon after the onset of infarction. However, no bcl-2 was found in the infarcted area itself. Bax is a member of the bcl-2 family and, when overexpressed, accelerates apoptosis. It also counters the death repressor activity of bcl-2. ${ }^{39}$ In contrast to bcl-2, Bax has a low basal expression in human hearts without cardiac disease. ${ }^{37}$ The overexpression of Bax was found in two of 15 hearts at the acute stage of infarction (between six hours and 20 days after the onset of myocardial infarction (MI)). At the old stage (more than a month after the onset of MI) Bax overexpression was found in 10 of 12 hearts, predominantly in the areas surrounding infarcted areas. In these areas the expression of bcl-2, present in the acute stage, had disappeared. Therefore, the Bax to bcl-2 ratio is high and may be related to apoptotic cell death in these areas in the old infarction. ${ }^{37}$

\section{Fas}

In AMI, soluble Fas (sFas: an inhibitor of apoptosis) values increase, whereas sFas ligand (an inducer of apoptosis) values do not change. ${ }^{40}$ Circulating sFas values are significantly higher in acute MI than in old MI. Remarkably, sFas values increase in AMI independent of infarct size.

\section{IN VIVO ANIMAL MODELS}

\section{Apoptosis triggered by ischaemia and/or reperfusion?}

Cell death resulting from MI has been extensively investigated in vivo in various animal models. Usually, MI was induced by the occlusion of a major coronary artery.

Upon permanent occlusion of a coronary vessel in rats, apoptosis occurred in the ischaemic region, the area immediately bordering the ischaemic region and in the remote from ischaemia region. Therefore, it was suggested that apoptosis is the major determinant of infarct size. Necrosis occurred less often and was seen only in the ischaemic region. ${ }^{12}$ In a similar experiment in rats, Fliss and Gattinger also showed that apoptosis occurred after constant ischaemia. ${ }^{13}$ However, they found that apoptosis appeared solely in the ischaemic myocardium, not in the bordering or remote from ischaemia regions. Although reperfusion after 45 minutes of ischaemia appeared to attenuate apoptosis in the infarcted area, it enhanced apoptosis in the bordering zones and the remote from ischaemic regions. In a similar study in rats by Palojoki et $a l,{ }^{14}$ enhanced apoptosis was seen from 24 hours up to 12 weeks after experimental MI in the ischaemic area and in its 
border zone. Apoptosis was also increased in the remote noninfarcted tissue up to four weeks after infarction. ${ }^{14}$ However, in this study apoptosis was measured by the TUNEL method only.

\section{"A better understanding of the cellular mechanisms that control apoptosis could lead to therapeutic strategies to limit the amount of tissue damage in patients with myocardial infarction"}

Apoptosis after ischaemia/reperfusion was also shown in an in vivo dog model in the ischaemic area. ${ }^{15}$ However, apoptosis was not found in this area in dogs subjected to ischaemia alone.

\section{Bcl-2 and Bax}

In an in vivo experiment in rats, DNA strand breaks were seen as early as three hours after coronary artery occlusion. ${ }^{41}$ Apoptosis was accompanied by a decrease in bcl-2 protein values and an increase in the expression of Bax, indicating a role for these proteins in the regulation of ischaemia induced apoptosis in rats. In another in vivo rat model it was found that EAT/ mcl-1, a bcl-2 related immediate early gene, is strongly upregulated as early as 30 minutes after coronary artery occlusion. ${ }^{16}$ In line with this, in transgenic mice overexpressing human bcl-2, myocardial reperfusion injury was reduced. ${ }^{42}$ This reduction of reperfusion injury correlated with a significant reduction in apoptosis, as measured by means of the TUNEL staining method only. In dogs, reperfusion resulted in reduced bcl-2 expression and increased Bax expression in the ischaemic area, whereas after permanent ischaemia, bcl-2 and Bax values did not change. ${ }^{15}$

\section{Fas}

In an in vivo rabbit model it was shown that Fas receptor expression was dramatically upregulated in the border zone of histologically infarcted myocardium after ischaemia/ reperfusion. ${ }^{17}$ In line with this, carvedilol, a vasodilating $\beta$ adrenoceptor antagonist and a potent antioxidant, caused a $77 \%$ reduction of apoptotic cells in the border zone and at the same time significantly reduced Fas receptor expression after ischaemia/reperfusion. ${ }^{17}$ In addition, in an in vivo rat model it was found that Fas receptor expression increased 131 fold in cardiomyocytes after coronary artery occlusion. ${ }^{43}$ These results indicate that the Fas receptor is involved in ischaemia/ reperfusion induced apoptosis in rabbit and rat hearts.

\section{Preconditioning}

Ischaemic preconditioning is a phenomenon whereby a series of brief periods of alternating ischaemia and reperfusion increase myocardial tolerance to the subsequent prolonged ischaemia. This phenomenon was first described by Murry et $\mathrm{al}^{44}$ Since then, numerous studies have shown the cardioprotective effect of preconditioning in different animal species and in humans. ${ }^{45-57}$

Piot et al showed that ischaemic preconditioning in rats caused a significant reduction in the amount of apoptosis and infarct size. ${ }^{18}$ However, the exact mechanisms by which ischaemic preconditioning causes this cardioprotective effect are still unclear. A correlative effect of reduced myocardial apoptosis, reduced Bax expression, increased bcl-2 expression, and reduced neutrophil accumulation in ischaemic preconditioning experiments in rats and dogs has been suggested. ${ }^{19} 20$ Ischaemic preconditioning also seems to attenuate the ischaemia/reperfusion induced activity of caspase 1 and caspase 3 in rats ${ }^{21}$.

Accumulative evidence points to a role for protein kinase $\mathrm{C}$ (PKC) as a final common pathway in the cardioprotective effect of ischaemic preconditioning in rats. It was shown that pretreatment with calphostin $\mathrm{C}$, an inhibitor of $\mathrm{PKC}$, completely aborted the protective effect of ischaemic preconditioning on infarct size $\mathrm{s}^{58}$ and most apoptosis ${ }^{22}$ caused by ischaemia/reperfusion. Piot et al suggest that in ischaemic preconditioning possible end effectors of PKC are ATP sensitive potassium channels, because it was shown that the activation of mitochondrial $\mathrm{K}_{\text {ATP }}$ channels induces preconditioning against MI and reduces ischaemic/reperfusion induced apoptosis through the PKC signalling pathway. ${ }^{59}$

\section{Reactive oxygen species}

Increased oxidative stress was found to coexist with apoptosis in the remote non-infarcted rat myocardium after myocardial infarction. ${ }^{60}$ Longterm treatment with the antioxidants probucal and pyrrolidine dithiocarbamate, starting three days after MI in an in vivo rat ischaemia/reperfusion model, attenuated oxidative stress, myocyte apoptosis, caspase 3 activity, and the expression of p53, Bax, and caspase 3 protein in the remote non-infarcted myocardium. ${ }^{61}$ These findings indicate a causal relation between oxidative stress and apoptosis in the remote non-infarcted rat myocardium after MI.

\section{p53}

One hypothesised general molecular mediator of hypoxia induced apoptosis is the tumour suppressor transcription factor p53. It is suggested that p53 may induce apoptosis by stimulating the expression of Bax and/or repression of bcl-2 expression. $^{62}$ In contrast, in an in vivo model of apoptosis in wild-type mice and homozygous p53 knockout mice, it was found that ischaemia induced apoptosis occurred as readily in the p53 knockout mice as in wild-type mice. ${ }^{23}$ This finding indicates the existence in the heart of other, p53 independent, mechanisms of postischaemic apoptosis.

\section{JAK/STAT pathway}

In general, the Janus kinase/signal transducer and activator of transcription (JAK/STAT) pathway is reported to be involved in the transduction of cytoprotective signals in stressful conditions, such as hypoxia. ${ }^{63}{ }^{64}$ In an in vivo rat experiment, it was found that rats treated with a specific JAK-2 inhibitor AG-490, subsequent to ischaemia, did show a significant upregulation of caspase 3 activity and Bax expression, in addition to a significant increase in the number of apoptotic cells compared with control rats. ${ }^{65}$ These results indicate an antiapoptotic role for the JAK/STAT signalling pathway in the rat myocardium.

\section{Stress activated protein kinases}

The stress activated protein kinase (SAPK) signalling pathway has recently been implicated as an important mediator of apoptosis. ${ }^{66}$ SAPK activity is dramatically increased in rabbit hearts after ischaemia/reperfusion. ${ }^{17}$ Carvedilol, a $\beta$ adrenoceptor antagonist, when administered before reperfusion, significantly reduces apoptosis and significantly attenuates SAPK activity in rabbit hearts. ${ }^{17}$

Other stress activated mitogen activated protein kinases (MAPKs) have also been implicated in ischaemia/reperfusion induced apoptosis. p38 MAPK activity was induced in the rat heart as early as 15 minutes after coronary artery occlusion and also by reperfusion. ${ }^{67}$ Jun $\mathrm{N}$-terminal kinase (JNK) activity was also induced after ischaemia followed by reperfusion in the rat heart, although no JNK activity was seen as a result of ischaemia alone. Both MAPK and JNK are suggested to play a role in apoptosis because the time course of the activation patterns of these kinases and the increase in DNA laddering are highly correlated. ${ }^{67}$

\section{Insulin-like growth factor I}

Insulin-like growth factor I (IGF-I) appeared to be cardioprotective in a rat in vivo ischaemia/reperfusion model. ${ }^{68}$ When administered one hour before ischaemia, IGF-I attenuated 
polymorphonuclear neutrophil accumulation in the ischaemic area. Furthermore, IGF-I significantly attenuated the incidence of myocyte apoptosis after myocardial ischaemia and reperfusion. ${ }^{6}$ In addition, in transgenic mice overexpressing human IGF-I, it was found that both apoptosis and necrosis were attenuated in the viable myocardium after infarction. ${ }^{69}$

\section{"Insulin-like growth factor I appeared to be cardioprotective in a rat in vivo ischaemia/reperfusion model"}

Interestingly, IGF-I also promotes the release of physiological amounts of nitric oxide (NO). ${ }^{70}{ }^{71}$ In an in vivo mouse model it was shown that the inhibition of endogenous NO synthesis increased apoptosis during ischaemia. ${ }^{72}$ It seems that endogenous NO suppresses apoptosis by interfering with the caspase cascade, because the inhibition of endogenous NO correlated with increased caspase activity, whereas bcl-2 and Bax protein values were unchanged. ${ }^{72}$ However, it cannot be excluded that reduced apoptosis is a systemic effect rather than an effect of endogenous NO on the caspase machinery because NO, through an effect on microcirculation, influences perfusion.

\section{Heat shock protein}

Heat shock protein 70 (HSP70) is a self preservation protein that maintains cellular homeostasis under environmental stress. HSP70 acts as a molecular chaperone and plays an important role in protein folding, assembly, transport, and degradation although it also helps to prevent protein denaturation and aggregation. ${ }^{73}$ In an in vivo experiment in rats it was shown that overexpression of HSP70, via gene transfection, reduced apoptosis after ischaemia/reperfusion. ${ }^{74}$

\section{Calcineurin}

In rats adenovirally transfected with constitutively active calcineurin cDNA, ischaemia/reperfusion induced apoptosis was significantly attenuated, whereas the inhibition of endogenous calcineurin reversed the antiapoptotic effects. ${ }^{75}$ These results indicate a calcineurin dependent protection from apoptosis in cardiomyocytes.

\section{Tumour necrosis factor}

Recently it was found that tumour necrosis factor (TNF) is expressed within the myocardium of rats $^{76}$ and $\operatorname{dogs}^{77}$ in response to ischaemic injury. ${ }^{78}$ TNF has dual effects with regard to apoptosis. It provokes the expression of several antiapoptotic factors in a variety of mammalian cell types, although it can also induce apoptosis in mouse fibroblasts. ${ }^{79}$ In an in vivo ischaemia model in mice lacking none, one, or both types of TNF receptor, it was found that endogenous TNF protected cardiomyocytes against ischaemia induced apoptosis. ${ }^{80}$

\section{Caspases}

In general, caspases form a key step in the process of apoptosis. In a rat and rabbit in vivo ischaemia/reperfusion model, the tripeptide inhibitor of the caspase interleukin $1 \beta$ converting enzyme (ICE) family of cysteine proteases-ZVAD-fmkwas able to reduce infarct size and attenuated the amount of TUNEL positive cardiomyocytes. ${ }^{24}$ Remarkably, ZVAD-fmk might also interfere with myocardial necrotic cell death because it was found that ICE-like inhibitors attenuate both apoptotic and necrotic cell death in an in vitro system of chemical hypoxia. ${ }^{81}{ }^{82}$ Therefore, the reduction in infarct size might result from both reduced apoptosis and necrosis. In a similar model, YVAD-aldehyde, a caspase l-like protease inhibitor and DEVD-aldehyde, a caspase 3-like protease inhibitor, both attenuated the amount of myocardial apoptosis. ${ }^{83}$ Remarkably however, these two inhibitors did not reduce infarct size.
Overexpression of cardiac specific caspase 3 in transgenic mice induced transient depression of cardiac function, caused abnormal ultrastructural damage to the nucleus in addition to the mitochondrial and myofibrillar content, and increased infarct size. However, it did not induce an apoptotic response that progressed through to the late apoptotic phases, such as the production of apoptotic bodies. ${ }^{84}$

\section{Kallikrein}

The activity of kallikrein leads to the production of intact kinins, which act through specific receptors to activate second messengers to trigger biological effects such as vasodilation and vasoconstriction. ${ }^{85}$ The tissue kallikrein-kinin system components have been identified in the heart. ${ }^{86-88}$ In an in vivo rat experiment it was found that, through the delivery of the human tissue kallikrein gene, myocardial infarction and apoptosis were significantly reduced after ischaemia/ reperfusion injury. ${ }^{85}$ This effect of kallikrein is probably mediated through an NO-cGMP dependent signal transduction pathway. ${ }^{85}$

\section{Influence of age on apoptosis}

In a mouse in vivo ischaemia/reperfusion model it was found that there are age associated differences in reperfusion injury between young (6-8 months) and old (22-24 months) mice. ${ }^{89}$ It was shown that mortality was higher and infarct size was significantly larger in old animals, compared with young animals. Furthermore, the occurrence of DNA fragmentation was significantly higher in old hearts, indicating that the amount of apoptosis as a result of ischaemia/reperfusion is greater in old hearts. ${ }^{89}$ A higher occurrence of DNA fragmentation was also seen in an in vivo rat model. ${ }^{90}$ In this model, DNA fragmentation began and peaked earlier after infarction in the old heart than in the young heart, and bcl-2 and Bax showed a heightened baseline expression in the old hearts, which might indicate a higher degree of chronic stress in the old hearts. ${ }^{90}$ The hearts of older animals might therefore be more susceptible to ischaemia/reperfusion related apoptosis.

\section{ISOLATED ANIMAL HEARTS}

The studies described below with isolated hearts were carried out in hearts that were perfused with a perfusion buffer (usually a Krebs Heinselheit buffer) in an atmosphere of $95 \% \mathrm{O}_{2}$ and $5 \% \mathrm{CO}_{2}$ at $37^{\circ} \mathrm{C}$.

\section{Fas}

In isolated rat and mouse hearts subjected to ischaemia/ reperfusion, it was found that soluble Fas ligand was released after the onset of reperfusion..$^{27}$ Isolated mouse hearts lacking functional Fas show a significant reduction in cell death after ischaemia/reperfusion, compared with wild-type mice, suggesting a proapoptotic role. ${ }^{27}$

\section{Preconditioning}

In isolated rat hearts, it has also been shown that preconditioning reduces cardiomyocyte apoptosis and oxidative stress. ${ }^{28} 91$ Preconditioning in this model induced tyrosine kinase phosphorylation, leading to the activation of MAPKAP kinase 2 and p38 MAPK, and was associated with induced expression of bcl-2 mRNA and translocation and activation of the nuclear transcription factor nuclear factor $\kappa \mathrm{B}(\mathrm{Nf} \kappa \mathrm{B}) .^{.1}$ AP-1, another transcription factor, which is highly upregulated by prolonged ischaemia followed by reperfusion, is unaffected by preconditioning. ${ }^{28}$ Preincubation with DMTU, a hydroxyl radical scavenger, or SN50, an NFKB blocker, abolished the antiapoptotic effect of preconditioning, and this is possibly related to the prevention of the preconditioning induced upregulation of bcl-2..$^{91}$ Indeed, in rat hearts treated with antisense bcl-2 oligonucleotides, the antiapoptotic effects 
of preconditioning were abolished, as was the reduced oxidative stress, suggesting an antioxidant role for bcl-2 in preconditioning. ${ }^{92}$

\section{Reactive oxygen species}

In isolated perfused rat hearts it was shown that apoptosis only occurred in reperfused hearts when oxidative stress was induced. ${ }^{29}$ The reperfusion injury effects could be reversed by epselen, which removed the oxidative stress from the heart, indicating that oxidative stress in this model plays a role in the development of ischaemia/reperfusion related apoptosis. ${ }^{29}$

\section{p53}

In contrast to animal in vivo studies, in isolated rat hearts, mRNA encoding the proapoptotic oncogene p53 was highly induced by reperfusion, whereas it was barely detected after ischaemia alone. ${ }^{30}$ Ischaemic preconditioning prevented the activation of p53 and inhibited apoptosis. ${ }^{30}$

\section{JAK/STAT pathway}

Isolated rat hearts subjected to ischaemia/reperfusion show activation of STAT5A and STAT6. Treatment of these hearts with tyrphostin AG490, which inhibits JAK2 phosphorylation, resulted in reduced infarct size and apoptosis.93

\section{Stress activated mitogen activated protein kinases}

In isolated rat hearts, SAPK activity is raised as a result of ischaemia/reperfusion. ${ }^{94}$ Treatment of these hearts with magnesium tanshinoate $\mathrm{B}$, a bioactive compound isolated from Danshen, resulted in a reduction of apoptotic nuclei. Furthermore, it abolished the raised SAPK activity, suggesting a proapoptotic role for SAPK in ischaemia/reperfusion induced apoptosis in rats. ${ }^{94}$

\footnotetext{
"In addition, p38 MAPK and JNK activities were greatly increased after ischaemia/reperfusion in an isolated rat heart model"
}

It has also been found that myocardial ischaemia/ reperfusion results in the activation of p38 MAPK, whereby reperfusion has a more profound effect on p38 MAPK activity than ischaemia alone. ${ }^{31} 679596$ In line with this, in isolated rabbit hearts the p38 MAPK inhibitor SB 203580 greatly reduced postischaemic myocardial apoptosis and significantly improved cardiac function recovery after reperfusion. ${ }^{31}$ In addition, p38 MAPK and JNK activities were greatly increased after ischaemia/reperfusion in an isolated rat heart model. ${ }^{97}$ However, inhibition of the extracellular signal related kinase (ERK) significantly increased the number of apoptotic cells, suggesting that p38 MAPK and JNK mediate myocardial apoptosis and that ERK plays a protective role. ${ }^{97}$

\section{Heat shock protein}

Recent reports indicate a role for the small HSP family in ischaemic preconditioning. ${ }^{98}{ }^{99} \alpha \mathrm{B}$ crystalline is a member of the small HSP family and is the most abundantly expressed stress protein in the heart. ${ }^{100}$ In transgenic mice overexpressing $\alpha \mathrm{B}$ crystalline, it was found that the overexpression of $\alpha \mathrm{B}$ crystalline results in attenuated apoptotic myocardial cell death, decreased oxidative stress, and a decrease in the extent of infarction, upon ischaemia/reperfusion. ${ }^{101}$

\section{Caspases}

In isolated rat hearts subjected to prolonged ischaemia, a significant accumulation of cytochrome c occurred in the cytosol, which was accompanied by activation of caspase 3-like proteases. ${ }^{102}$ In contrast, caspase l-like proteases were not activated.

\section{ISOLATED AND CULTURED CARDIOMYOCYTES} Apoptosis induced by hypoxia?

Exposure of cultured neonatal rat cardiomyocytes to chronic hypoxia causes the activation of the terminal apoptotic machinery, including cytochrome c release, effector caspase activation, and cleavage of the death substrate poly(ADPribose) polymerase (PARP)..$^{22}{ }^{103}$ The same effects were seen after exposure of neonatal rat cardiomyocytes to metabolic inhibition using 2-deoxyglucose. ${ }^{104}$ These results indicate that both hypoxia and metabolic inhibition induce apoptosis through the mitochondrial pathway. Reoxygenation further increased the number of apoptotic cells and resulted in a decrease in bcl-2 and an increase in the Fas receptor. ${ }^{32}$ Interestingly, these effects could be countered by incubation with either recombinant transforming growth factor $\beta 1$ (TGF- $\beta 1)$ or aggregated platelet supernatant. ${ }^{32}$ Aggregated platelet supernatant was found to protect the heart from reperfusion induced apoptosis, partly because of platelet released TGF- $\beta 1 .{ }^{32}$ In contrast, in isolated ventricular rat cardiomyocytes, 60 minutes of anoxia alone did not increase annexin V staining, but induced a significant increase in propidium iodide staining. ${ }^{105}$ An increase in annexin V staining was seen only after a period of reperfusion. In contrast, in another study with rat cardiomyocytes anoxia/reoxygenation caused necrosis in isolated rat cardiomyocytes but failed to induce apoptosis. ${ }^{33}$

\section{Fas}

In an in vitro study using neonatal rat cardiomyocytes it was shown that the expression of mRNA for the Fas antigen was upregulated twofold under hypoxic conditions, whereby Fas receptor and Fas ligand induction correlated with induced apoptosis. ${ }^{106}$ Recently, it was also shown that STATl induced Fas receptor and Fas ligand expression after ischaemia/ reperfusion in neonatal rat cardiomyocytes. ${ }^{107}$ Furthermore, in primary adult rat culture, ischaemia followed by reperfusion caused a pronounced increase in sensitivity to the apoptotic effects of soluble Fas ligand. ${ }^{27}$

\section{Preconditioning}

In isolated adult cardiomyocytes from rabbit hearts, ischaemic preconditioning attenuated cardiomyocyte apoptosis, which correlated with a diminution in the fall of intracellular $\mathrm{pH}^{34}$ The antiapoptotic effects of ischaemic preconditioning could be prevented by blocking the vacuolar proton ATPase, suggesting that the maintenance of intracellular $\mathrm{pH}$ homeostasis attenuates apoptosis in ischaemic preconditioning. ${ }^{34}$

\section{Reactive oxygen species}

Oxidative stress through $\mathrm{H}_{2} \mathrm{O}_{2}$ and the NO donor, $\mathrm{N}_{2}$-acetyl-Snitroso-DL-penicillinaminamide (SNAP), induced apoptosis in ventricular cardiomyocytes isolated from a rat heart. ${ }^{35}$ In isolated rat cardiomyocytes, a correlation between the apoptotic effect of SNAP or YC-1 (a direct activator of soluble guanylyl cyclase) and the increased activity of soluble guanylyl cyclase (that is, the intracellular cGMP content) was seen. ${ }^{35}$ It has been suggested that NO induces apoptosis in a cGMP dependent manner and necrosis in a cGMP independent manner.

Both reactive oxygen species $\mathrm{H}_{2} \mathrm{O}_{2}$ and $\mathrm{O}_{2}^{-}$induced apoptosis in neonatal rat cardiomyocytes, which was associated with an increase in $\mathrm{p} 53$ protein content, whereas protein concentrations of bcl-2 and Bax were unaltered. ${ }^{108}$ Interestingly, both $\mathrm{H}_{2} \mathrm{O}_{2}$ and $\mathrm{O}_{2}^{-}$induced apoptosis through distinct pathways. $\mathrm{H}_{2} \mathrm{O}_{2}$ induced the release of cytochrome c, activation of CPP32, and cleavage of PARP, through Bax and Bad (another proapoptotic bcl-2 family member). This can be suppressed by the pharmacological opening of the mitochondrial ATP sensitive $\mathrm{K}^{+}$channels by diazoxide, which preserves mitochondrial integrity. ${ }^{109}$ In contrast, $\mathrm{O}_{2}^{-}$promoted apoptosis through the 


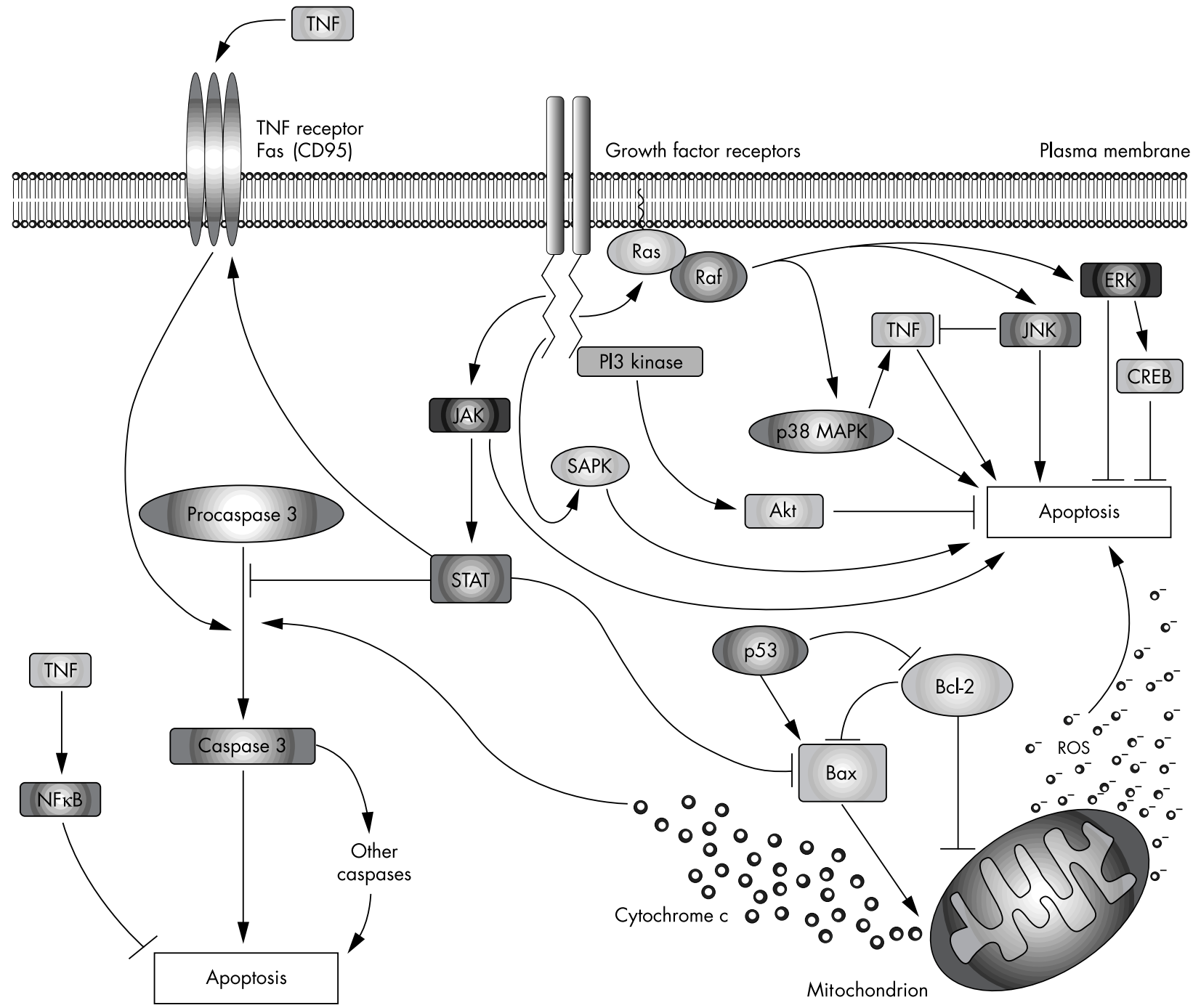

Figure 1 Overview of the signal transduction pathways related to ischaemia/reperfusion induced apoptosis in cardiomyocytes. In this figure, inducing or activating effects are depicted by an arrow and inhibitory effects are depicted by a blocked line. Akt, protein kinase B; ERK, extracellular signal related kinase; JAK, Janus kinase; JNK, Jun N-terminal kinase; MAPK, mitogen activated protein kinase; NFKB, nuclear factor $\mathrm{KB}$; PI3 kinase, phosphatidylinositol 3'-kinase; ROS, reactive oxygen species; SAPK, stress activated protein kinase; STAT, signal transducer and activator of transcription; TNF, tumour necrosis factor.

activation of Mch2 $\alpha$ (a caspase family member and the only known laminase $\left.{ }^{110}\right)$, which cleaves its substrate lamin A (a type of filament protein which, together with lamins B and C, forms the nuclear lamina of eukaryotic cells). ${ }^{108}$

\section{p53}

Exposure of neonatal rat cardiomyocytes to 24 hours of hypoxia resulted in an increase of apoptosis, as measured by DNA laddering, detection of DNA fragmentation by enzyme linked immunosorbent assay, and annexin V-FLUOS/ propidium iodide double staining. ${ }^{111}$ Reoxygenation further increased the number of apoptotic cells. Hypoxia resulted in the upregulated expression of the bcl-2 and p53 proteins, whereas reoxygenation downregulated bcl-2 expression and further upregulated p53. ${ }^{111}$ Chinonin, a natural antioxidant, significantly attenuated hypoxia/reoxygenation induced apoptosis, downregulated p53 expression, and induced bcl-2 upregulation. ${ }^{111}$

"It has been suggested that p53 plays a crucial role in the induction of apoptosis as a result of hypoxia in cultured neonatal rat cardiomyocytes"
In another experiment in neonatal rat cardiomyocytes, 48 hours of hypoxia resulted in an increase of TUNEL positive cells and an increase in $\mathrm{p} 53$ protein, which was not accompanied by increased DNA laddering. ${ }^{12}$ This was also accompanied by increased expression of $\mathrm{p} 2$ 1/WAF-1/CIP-1, a well characterised target of p53 transactivation. ${ }^{12}$ Because overexpression of wild-type $\mathrm{p} 53$ by adenovirus mediated gene transfer is sufficient to induce apoptosis in neonatal rat cardiomyocytes under normoxic conditions, ${ }^{112}$ it has been suggested that $\mathrm{p} 53$ plays a crucial role in the induction of apoptosis as a result of hypoxia in cultured neonatal rat cardiomyocytes.

In contrast, equivalent apoptosis was measured in hypoxic/ acidotic cardiomyocytes isolated from the hearts of wild-type or homozygous p53 knockout mice. ${ }^{36}$ However, in these mice severe chronic hypoxia alone was not sufficient to induce apoptosis, but had to be accompanied by a decrease in the extracellular $\mathrm{pH}$ to induce apoptosis, whereas reoxygenation resulted in increased apoptosis in a p53 independent manner. These results indicate that the fall in extracellular $\mathrm{pH}$ or reoxygenation, but not solely hypoxia, is responsible for the induction of apoptosis in murine cardiomyocytes, and that the process is a p53 independent one. 
Table 2 Overview of proapoptotic and antiapoptotic mediators in ischaemia/reperfusion induced apoptosis in cardiomyocytes

\begin{tabular}{|c|c|c|c|c|}
\hline Type of mediator & Human & In vivo animal & $\begin{array}{l}\text { Isolated animal } \\
\text { hearts }\end{array}$ & Isolated and cultured cardiomyocytes \\
\hline Proapoptotic & $\begin{array}{l}\text { Bax }^{3739} \\
\text { Soluble Fas ligand }{ }^{40}\end{array}$ & 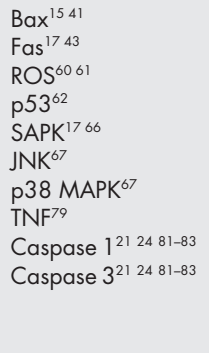 & $\begin{array}{l}\text { Fas }^{27} \\
\text { Bcl-2 }^{92} \\
\text { ROS }^{29} \\
\text { p53 } 30 \\
\text { JAK }^{33} \\
\text { SAPK }^{94} \\
\text { p38 MAPK } \\
\text { JNK }^{97}\end{array}$ & $\begin{array}{l}\text { Soluble Fas ligand }{ }^{27} \\
\text { ROS }^{35} 108 \\
\text { p53 } \\
\text { p38 MAPK } \\
\text { JNK }^{112} \\
\text { TNF- }^{112}{ }^{112} \\
\text { Caspases }^{32103} \\
\text { Cytochrome c }^{32} 103 \\
\text { Fas receptor } \\
\text { Vacualar proton ATPase } \\
\text { Bad }^{109} \\
\text { Bax }^{109}\end{array}$ \\
\hline Antiapoptotic & $\begin{array}{l}\text { Bcl-2 } 2^{37-39} \\
\text { Soluble Fas }\end{array}$ & $\begin{array}{l}\text { Bcl-2 } 2^{151741} \\
\text { PKC }^{225859} \\
\text { JAK/STAT } \\
\text { IGF-I } \\
\text { IG 69 } \\
\text { NO }^{70-72} \\
\text { HSP7O }^{74} \\
\text { Calcineurin } \\
\text { TNF } \\
\text { Kallikrein }^{85}\end{array}$ & $\begin{array}{l}\text { ERK }^{97} \\
\alpha \beta \text { Crystalline }^{101}\end{array}$ & $\begin{array}{l}\text { TGF- } \beta 1^{32} \\
\text { Mitochondrial ATP sensitive } \mathrm{K}^{+} \text {ch. }^{109} \\
\text { MEKK } 1^{114} \\
\text { JNK }^{114} \\
\text { HGF }^{116} \\
\text { ERK }^{117} 119 \\
\text { PI3 kinase } \\
\text { Akt }{ }^{118} 1119 \\
\text { HSP70 } \\
\text { IGF-I }^{119} \\
\text { CREB } \\
\text { Bcl-2 } 2^{119} \\
\text { Calcineurin } \\
\text { TNF- } \alpha^{125}\end{array}$ \\
\hline
\end{tabular}

Akt, protein kinase B; CREB, cAMP response element binding protein; ERK, extracellular signal related kinase; HGF, hepatocyte growth factor; HSP, heat shock protein; IGF, insulin-like growth factor; JAK/STAT, Janus kinase/signal transducer and activator of transcription; JNK, Jun N-terminal kinase; MAPK, mitogen activated protein kinase; MEKK, MAPK kinase kinase; NO, nitric oxide; PKC, protein kinase C; ROS, reactive oxygen species; SAPK, stress activated protein kinase; TGF, transforming growth factor; TNF, tumour necrosis factor.

\section{The role of kinases}

In cultured neonatal rat cardiomyocytes, two distinct phases of p38 MAPK activation are seen during hypoxia; a transient activation that starts within 10 minutes of hypoxia and a sustained activation that starts after two hours of hypoxia. ${ }^{113}$ In this model, ERK2 and JNK are not activated. By using the specific p38 MAPK inhibitor SB 203580, apoptosis was attenuated, even when only the sustained activation of $\mathrm{p} 38$ MAPK was inhibited. This suggests that the sustained activation of p38 MAPK induces apoptosis in neonatal rat cardiomyocytes after hypoxia. ${ }^{113}$ In this study, however, the distinction between necrotic and apoptotic cells was made solely by differences in the morphology of their nuclei.

In agreement with this study, embryonic stem cell derived cardiomyocytes (ESCM) with targeted disruption of the MEKKl (a MAPK kinase kinase) gene were extremely sensitive, compared with wild-type ESCM, to $\mathrm{H}_{2} \mathrm{O}_{2}$ induced apoptosis. p38 MAPK was suggested to play a proapoptotic role by activating the production of TNF- $\alpha,,^{114}$ whereas an antiapoptotic role was suggested for MEKKl. MEKKl inhibits the production of TNF- $\alpha$ via the activation of JNK, suggesting an antiapoptotic role for JNK. In contrast, in rat neonatal cardiomyocytes transfected with antisense JNK DNA, condensation of the nuclei was inhibited after $\mathrm{H}_{2} \mathrm{O}_{2}$ treatment, suggesting a proapoptotic role for JNK. ${ }^{115}$

Treatment of both isolated adult rat cardiomyocytes and cultured mouse cardiomyocytes with hepatocyte growth factor (HGF), subsequent to oxidative stress, resulted in attenuated apoptosis, partially through the MEK-p44/42 MAPK pathway, ${ }^{116}$ suggesting an antiapoptotic role for HGF.

In neonatal rat cardiomyocytes, it was suggested that ERKs have an antiapoptotic role in response to raised $\mathrm{H}_{2} \mathrm{O}_{2}$ concentrations after oxidative stress, through the activation of cyclooxygenase 2 expression and subsequent prostaglandin production. ${ }^{117}$

\section{Insulin-like growth factor I}

In rat neonatal cardiomyocytes, treatment with IGF-I increased the activity of phosphatidylinositol 3'-kinase (PI3 kinase) and Akt (protein kinase B). ${ }^{118}{ }^{119}$ Interestingly, in cardiomyocytes infected with an adenovirus carrying constitutively active forms of PI3 kinase or Akt, apoptosis is significantly inhibited after hypoxic treatment. ${ }^{118}$ Indeed, in another study it was found that the inhibition of PI3 kinase or Akt abolished the antiapoptotic effects of IGF-I. ${ }^{119}$ In neonatal rat cardiomyocytes, IGF-I did prevent apoptosis after hypoxia, which also could be suppressed with genistein, a tyrosine kinase inhibitor, and PD-098059, a MAPK inhibitor. ${ }^{118}$ Subsequently, it was also found that IGF-I exerts its antiapoptotic effect through ERK1 and ERK2, resulting in activation of the transcription factor cAMP response element binding protein, which induces bcl-2 expression. ${ }^{119}$

\section{Heat shock protein}

A significant reduction of stress induced apoptosis was found in cardiomyocytes isolated from rat hearts overexpressing HSP70. $^{74}{ }^{120-122}$

\section{Calcineurin}

In $\mathrm{H}_{2} \mathrm{O}_{2}$ treated neonatal rat cardiomyocytes, apoptosis was almost completely abolished by endothelin l, a growth promoting peptide. ${ }^{123}$ In this study, apoptosis was measured by TUNEL, DNA laddering, morphological features, cytofluorometric analysis, and caspase 3 cleavage. Inhibition of calcineurin countered the antiapoptotic effects of endothelin $\mathrm{l}$, indicating a role for calcineurin in the antiapoptotic pathway of endothelin 1.

\section{Tumour necrosis factor}

In rat cardiomyocytes it was shown that physiologically relevant concentrations of TNF- $\alpha$ induced apoptosis (as measured by single cell microgel electrophoresis of nuclei and 
by morphological and biochemical criteria). ${ }^{124}$ The production of the second messenger sphingosine was also upregulated by TNF- $\alpha$, indicating the possible involvement of sphingosine in TNF- $\alpha$ mediated cardiomyocyte apoptosis, and it was shown that treatment with sphingosine strongly induced apoptosis in rat cardiomyocytes. ${ }^{124}$ However, in neonatal rat cardiomyocytes and H9c2 cells it was also shown that TNF- $\alpha$ activates both proapoptotic and antiapoptotic pathways. ${ }^{125}$ This antiapoptotic signal was mediated via the translocation of $\mathrm{NF \kappa B}$.

\section{DISCUSSION}

In recent years much evidence has implicated apoptosis in myocardial cell loss in ischaemia/reperfusion injury. In vivo studies in humans and in animals, and in vitro studies in isolated animal hearts and cultured cardiomyocytes, all indicate that apoptosis contributes to the death of cardiomyocytes as a result of ischaemia/reperfusion injury. Here, we present an overview of recent studies into ischaemia/reperfusion induced apoptosis in cardiomyocytes in various models and of the molecular mechanisms underlying this process (fig 1; table 2).

One of the conflicting areas in the study of apoptosis in the heart is the mechanism of induction. In some studies, apoptosis was found to be induced by ischaemia alone, and after ischaemia followed by reperfusion, ${ }^{6-8}{ }^{10^{12-15}}$ whereas in other studies ischaemia alone was not sufficient to trigger apoptosis. ${ }^{15} 72105$ The absence of apoptosis during ischaemia can be explained by the notion that during ischaemia intracellular ATP stores are depleted. This absence of intracellular ATP might prevent the occurrence of apoptosis because apoptosis is an energy requiring process.

Studies are also conflicting with respect to the area of the heart in which apoptosis is found. In humans, apoptosis seems to occur primarily in the border zone of the ischaemic region $^{6-8} 10$ and, according to some studies, in the remote from ischaemia regions. ${ }^{8}{ }^{10}$ However, in vivo animal studies have demonstrated apoptosis both in the ischaemic region and the ischaemic border zone. In contrast, in some studies ischaemia caused apoptosis in the ischaemic region alone, whereas reperfusion caused a decrease in apoptotic cells in the ischaemic region and an increase in apoptotic cells in the ischaemic border zone and the remote from ischaemia regions. ${ }^{13}{ }^{14}$ These differences, with respect to the mechanism of induction of apoptosis and for the area in which apoptosis was found, theoretically could be explained by the different methods of measuring apoptosis that were used.

\section{"One of the conflicting areas in the study of apoptosis} in the heart is the mechanism of induction"

The TUNEL staining method is now the most widely used marker for apoptosis in cardiomyocytes. However, it has become increasingly clear that the TUNEL assay is prone to false positive and negative results. ${ }^{126}$ For instance, the staining kinetics of TUNEL is dependent on the reagent concentration, the extent of proteolysis, and fixation of the tissue. Furthermore, non-specific staining may be caused by active RNA synthesis and DNA damage in necrotic cells. ${ }^{126}$ It is therefore important to standardise the TUNEL assay carefully by using DNAse treated tissue sections. Furthermore, these TUNEL positive cells must be characterised and a sufficient number of microscopic fields must be analysed. Even then, other methods of measuring apoptosis such as DNA laddering on agarose gels or the evaluation of apoptotic morphology should be combined with TUNEL to confirm the results.

The TUNEL method can also be used in electron microscopy analysis. In this method, the fragmented DNA is labelled using components of the ApopTag kit and subsequently with gold. In this way, nuclei can be analysed for TUNEL positivity and apoptotic morphology at an ultrastructural level at the same time. ${ }^{105}{ }^{127}$ However, a limitation of electron microscopic techniques is the small number of cells that can be analysed.

The detection of DNA fragments (DNA laddering) of sizes equivalent to mononucleosomes and oligonucleosomes is considered a trademark for apoptosis. ${ }^{128-130}$ The analysis of these fragments on agarose gel results in a "ladder" pattern. In necrosis, DNA is cleaved at random, thus creating DNA fragments that vary greatly in size. On agarose gels, these fragments produce a smear. However, it is important to bear in mind the fact that in the heart cardiomyocytes are not the only cells that are prone to apoptosis. When DNA laddering is used to analyse cardiac homogenates, apoptotic granulocytes or endothelial cells may contribute to the laddering, making it uncertain that it results from the apoptosis of cardiomyocytes alone. ${ }^{25}$

Another often used marker for apoptosis is annexin V. Annexin $\mathrm{V}$ binds with high affinity to phosphatidylserine (after its translocation via the process of membrane flip flop) and labelled annexin $\mathrm{V}$ has been used to detect apoptosis both in vivo and in vitro. ${ }^{11} 26105131132$ It has been suggested that annexin $\mathrm{V}$ could have an immediate clinical use in patients for live image apoptosis monitoring. ${ }^{11}{ }^{131}$ An advantage of annexin $\mathrm{V}$ staining over the TUNEL method is that it can detect early apoptosis. ${ }^{105}$ Indeed, cardiomyocytes stained with annexin V did not display late apoptotic morphology. ${ }^{26}$ However, like TUNEL, annexin V might not be a totally specific marker for apoptosis because it can also bind to membrane fragments of late necrotic cells or flip flopped cells that have not undergone apoptosis/necrosis. Therefore, conclusions based solely on annexin $\mathrm{V}$ staining should be drawn with caution.

Thus, to date, there is no totally specific apoptotic marker that solely detects apoptotic cells, so that a combination of techniques should always be used to detect apoptosis.

Regardless of the limitations of the different methods for determining apoptosis, it is suggested that cardiomyocyte apoptosis as a result of ischaemia/reperfusion does not share all the classic hallmarks of apoptosis originally described for other cells. ${ }^{3}$ For instance, electron microscopic analysis and histological studies have revealed only sporadic cardiomyocytes with classic late apoptotic morphology, such as the presence of apoptotic bodies. ${ }^{25}$ This could be explained by the involvement of common mediators in both apoptosis and necrosis, ${ }^{82}$ or an interchange between apoptosis and necrosis. It has been suggested that inflammatory cell activation could alter the process of apoptosis. Entman et al showed in reperfused canine myocardium that the presence of adhesion molecules on myocytes may allow the attachment of neutrophils and superoxide production, thereby converting apoptosis to necrosis. ${ }^{133-136}$

In line with this, in a recent study we have shown that cardiomyocytes that underwent flip flop of the plasma membrane (and were therefore annexin $\mathrm{V}$ positive but caspase 3 negative) bind secretory type II phospholipase A2 and subsequently potentiate the binding of the acute phase protein, $\mathrm{C}$ reactive protein (our unpublished data, 2002).

Another cause of the conversion of apoptosis to necrosis might be the depletion of ATP. In an ischaemia/reperfusion study, Lieberthal et al showed that the severity and duration of ATP depletion determines the mechanism of death, at least in proximal tubular cells: cells with an intracellular ATP concentration below a certain threshold become necrotic, whereas an ATP value above that threshold induces apoptosis. ${ }^{137}$ It is likely that ATP plays a similar role in cardiomyocytes because ischaemia results in ATP depletion. Indeed, neonatal rat cardiomyocytes subjected to metabolic inhibition and subsequent ATP depletion favour necrotic cell death, whereas metabolic inhibition under ATP replenishing conditions increased the proportion of apoptotic cells, as determined by nuclear morphology and DNA fragmentation. ${ }^{138}$ These authors suggested a model in cardiomyocytes in which intracellular ATP concentrations dictate the means of cell death-via necrosis 


\section{Take home messages}

- Numerous studies indicate that apoptosis is a mediator of cardiomyocyte cell death after myocardial infarction

- Because there is no totally specific marker that detects apoptotic cells, a combination of techniques should always be used to detect apoptosis

- A lack of completion of the apoptotic process seems to be related to low concentrations of ATP and/or a conversion of apoptosis to necrosis by a secondary inflammatory response

when ATP is depleted and via caspase activated apoptosis when ATP is present.

"There is no totally specific apoptotic marker that solely detects apoptotic cells, so that a combination of techniques should always be used to detect apoptosis"

In conclusion, numerous studies indicate that apoptosis can cause cardiomyocyte cell death after myocardial infarction, although the exact mechanisms of apoptosis within the heart are not known and the interpretation of studies is somewhat difficult because of the different methods used to determine apoptosis. Nevertheless, the process of apoptosis in the heart has a unique position within the field of apoptosis, analogous to other ischaemically challenged processes: a lack of completion of the apoptotic process seems to be related to a lack of ATP and/or a conversion of apoptosis to necrosis by a secondary inflammatory response.

\section{ACKNOWLEDGEMENTS}

This study was supported financially by the Netherlands Heart Foundation, grant number 97-088. Dr Niessen is a recipient of the Dr E Dekker program for the Netherlands Heart Foundation (D99025).

\section{Authors' affiliations}

P A J Krijnen, C J L M Meijer, H W M Niessen, Department of Pathology, VÚ University Medical Centre, PO Box 7075, 1007MB Amsterdam, The Netherlands

R Nijmeijer, Department of Cardiology, VU University Medical Centre

C E Hack, Department of Clinical Chemistry, VU University Medical

Centre

C A Visser, Department of Cardiology, VU University Medical Centre

\section{REFERENCES}

1 Kerr JF, Winterford CM, Harmon BV. Apoptosis. Its significance in cancer and cancer therapy. Cancer 1994;73:2013-26.

2 Majno G, Joris I. Apoptosis, oncosis, and necrosis. An overview of cell death. Am J Pathol 1995; 146:3-15.

3 Kerr JF, Wyllie AH, Currie AR. Apoptosis: a basic biological phenomenon with wide-ranging implications in tissue kinetics. $\mathrm{Br}$ Cancer 1972;26:239-57.

4 Saraste A, Pulkki K. Morphologic and biochemical hallmarks of apoptosis. Cardiovasc Res 2000;45:58-37.

5 Sloviter RS. Apoptosis: a guide for the perplexed. Trends Pharmacol Sci 2002;23: 19-24

6 Saraste A, Pulkki K, Kallajoki M, et al. Apoptosis in human acute myocardial infarction. Circulation 1997:95:320-3.

7 Toyoda $Y$, Shida T, Wakita N, et al. Evidence of apoptosis induced by myocardial ischemia: a case of ventricular septal rupture following acute myocardial infarction. Cardiology 1998;90:149-51

8 Piro FR, di Gioia CR, Gallo P, et al. Is apoptosis a diagnostic marker of acute myocardial infarction? Arch Pathol Lab Med 2000;1 24:827-31.

9 Abbate A, Melfi R, Patti G, et al. Apoptosis in recent myocardial infarction. Clin Ter 2000;151:247-5 1.

10 Olivetti G, Quaini F, Sala R, et al. Acute myocardial infarction in humans is associated with activation of programmed myocyte cell death in the surviving portion of the heart. J Mol Cell Cardiol 1996:28:2005-16

11 Hofstra L, Liem IH, Dumont EA, et al. Visualisation of cell death in vivo in patients with acute myocardial infarction. Lancet 2000;356:209-12.

12 Anversa $\mathbf{P}$, Cheng $W$, Liu $Y$, et al. Apoptosis and myocardial infarction. Basic Res Cardiol 1998;93(suppl 3):8-12.

13 Fliss H, Gattinger D. Apoptosis in ischemic and reperfused rat myocardium. Circ Res 1996;79:949-56.
14 Palojoki E, Saraste A, Eriksson A, et al. Cardiomyocyte apoptosis and ventricular remodeling after myocardial infarction in rats. Am J Physiol 2001;280:H2726-31

15 Zhao ZQ, Nakamura $M$, Wang NP, et al. Reperfusion induces myocardial apoptotic cell death. Cardiovasc Res 2000;45:651-60.

16 Matsushita K, Umezawa A, Iwanaga S, et al. The EAT/mcl-1 gene, an inhibitor of apoptosis, is up-regulated in the early stage of acute myocardial infarction. Biochim Biophys Acta 1999;1472:471-8.

17 Yue TL, Ma XL, Wang X, et al. Possible involvement of stress-activated protein kinase signaling pathway and Fas receptor expression in prevention of ischemia/reperfusion-induced cardiomyocyte apoptosis by carvedilol. Circ Res 1998;82:166-74.

18 Piot CA, Padmanaban D, Ursell PC, et al. Ischemic preconditioning decreases apoptosis in rat hearts in vivo. Circulation 1997;96:1598604 .

19 Wang NP, Bufkin BL, Nakamura $M$, et al. Ischemic preconditioning reduces neutrophil accumulation and myocardial apoptosis. Ann Thorac Surg 1999;67:1689-95

20 Nakamura $M$, Wang NP, Zhao ZQ, et al. Preconditioning decreases Bax expression, PMN accumulation and apoptosis in reperfused rat heart. Cardiovasc Res 2000;45:661-70.

21 Piot CA, Martini JF, Bui SK, et al. Ischemic preconditioning attenuates ischemia/reperfusion-induced activation of caspases and subsequent cleavage of poly(ADP-ribose) polymerase in rat hearts in vivo. Cardiovasc Res 1999;44:536-42.

22 Okamura T, Miura T, Iwamoto H, et al. Ischemic preconditioning attenuates apoptosis through protein kinase $\mathrm{C}$ in rat hearts. Am J Physio 1999;277:H1997-2001.

23 Bialik S, Geenen DL, Sasson IE, et al. Myocyte apoptosis during acute myocardial infarction in the mouse localizes to hypoxic regions but occurs independently of p53. J Clin Invest 1997;100:1363-72.

24 Yaoita H, Ogawa K, Maehara K, et al. Attenuation of ischemia/reperfusion injury in rats by a caspase inhibitor. Circulation 1998;97:276-81.

25 Gottlieb RA, Burleson KO, Kloner RA, et al. Reperfusion injury induces apoptosis in rabbit cardiomyocytes. J Clin Invest 1994;94:1621-8.

26 Dumont EA, Hofstra L, van Heerde WL, et al. Cardiomyocyte death induced by myocardial ischemia and reperfusion: measurement with recombinant human annexin $\mathrm{V}$ in a mouse model. Circulation 2000; 102:1564-8

27 Jeremias I, Kupatt C, Martin-Villalba A, et al. Involvement of CD95/Apol/Fas in cell death after myocardial ischemia. Circulation 2000;102:915-20.

28 Maulik N, Goswami S, Galang N, et al. Differential regulation of $\mathrm{Bcl}-2$, AP-1 and NF-kappaB on cardiomyocyte apoptosis during myocardial ischemic stress adaptation. FEBS Lett 1999;443:331-6.

29 Galang N, Sasaki H, Maulik N. Apoptotic cell death during ischemia/reperfusion and its attenuation by antioxidant therapy. Toxicology 2000;148:111-18.

30 Maulik N, Sasaki H, Addya S, et al. Regulation of cardiomyocyte apoptosis by redox-sensitive transcription factors. FEBS Lett 2000:485:7-12.

31 Ma XL, Kumar S, Gao F, et al. Inhibition of p38 mitogen-activated protein kinase decreases cardiomyocyte apoptosis and improves cardiac function after myocardial ischemia and reperfusion. Circulation 1999;99:1685-91

32 Yang BC, Zander DS, Mehta JL. Hypoxia-reoxygenation-induced apoptosis in cultured adult rat myocytes and the protective effect of platelets and transforming growth factor-beta(1).J Pharmacol Exp Ther platelets and transfor

33 Taimor G, Lorenz H, Hofstaetter B, et al. Induction of necrosis but not apoptosis after anoxia and reoxygenation in isolated adult cardiomyocytes of rat. Cardiovasc Res 1999:41:147-56.

34 Gottlieb RA, Gruol DL, Zhu JY, et al. Preconditioning rabbit cardiomyocytes: role of $\mathrm{pH}$, vacuolar proton ATPase, and apoptosis. J Clin Invest 1996;97:2391-8.

35 Taimor G, Hofstaetter B, Piper HM. Apoptosis induction by nitric oxide in adult cardiomyocytes via cGMP-signaling and its impairment after simulated ischemia. Cardiovasc Res 2000;45:588-94.

36 Webster KA, Discher DJ, Kaiser S, et al. Hypoxia-activated apoptosis of cardiac myocytes requires reoxygenation or a $\mathrm{pH}$ shift and is independent of p53. J Clin Invest 1999;104:239-52

37 Misao J, Hayakawa Y, Ohno $M$, et al. Expression of bcl-2 protein, an inhibitor of apoptosis, and Bax, an accelerator of apoptosis, in ventricular myocytes of human hearts with myocardial infarction. Circulation 1996;94:1506-12

38 Hockenbery DM, Zutter M, Hickey $W$, et al. BCL2 protein is topographically restricted in tissues characterized by apoptotic cell death. Proc Natl Acad Sci U S A 1991;88:6961-5.

39 Oltvai ZN, Milliman CL, Korsmeyer SJ. Bcl-2 heterodimerizes in vivo with a conserved homolog, Bax, that accelerates programmed cell death. Cell 1993:74:609-19.

40 Ohtsuka T, Hamada M, Sasaki O, et al. Clinical implications of circulating soluble Fas and Fas ligand in patients with acute myocardial infarction. Coron Artery Dis 1999;10:221-5.

41 Cheng W, Kajstura J, Nitahara JA, et al. Programmed myocyte cell death affects the viable myocardium after infarction in rats. Exp Cell Res 1996;226:316-27.

42 Brocheriou V, Hagege AA, Oubenaissa A, et al. Cardiac functional improvement by a human $\mathrm{Bcl}-2$ transgene in a mouse model of ischemia/reperfusion injury. Journal of Gene Medicine 2000;2:326-33.

43 Kajstura J, Cheng W, Reiss K, et al. Apoptotic and necrotic myocyte cell deaths are independent contributing variables of infarct size in rats. Lab Invest 1996;74:86-107. 
44 Murry CE, Jennings RB, Reimer KA. Preconditioning with ischemia: a delay of lethal cell injury in ischemic myocardium. Circulation 1986;74:1124-36

45 Urabe K, Miura T, Iwamoto T, et al. Preconditioning enhances myocardial resistance to postischaemic myocardial stunning via adenosine receptor activation. Cardiovasc Res 1993:27:657-62.

46 Cohen MV, Liu GS, Downey JM. Preconditioning causes improved wall motion as well as smaller infarcts after transient coronary occlusion in rabbits. Circulation 1991;84:341-9.

47 Hagar JM, Hale SL, Kloner RA. Effect of preconditioning ischemia on reperfusion arrhythmias after coronary artery occlusion and reperfusion in the rat. Circ Res 1991;68:61-8.

48 Osada M, Sato T, Komori S, et al. Protective effect of preconditioning on reperfusion induced ventricular arrhythmias of isolated rat hearts. Cardiovasc Res 1991;25:441-4.

49 Schott RJ, Rohmann S, Braun ER, et al. Ischemic preconditioning reduces infarct size in swine myocardium. Circ Res 1990;66:1133-42

50 Li YW, Whittaker P, Kloner RA. The transient nature of the effect of ischemic preconditioning on myocardial infarct size and ventricular arrhythmia. Am Heart J 1992; 123:346-53.

51 Liu Y, Downey JM. Ischemic preconditioning protects against infarction in rat heart. Am J Physiol 1992;263:H1 107-12.

52 Wolfe CL, Sievers RE, Visseren FL, et al. Loss of myocardial protection after preconditioning correlates with the time course of glycogen recovery within the preconditioned segment. Circulation 1993;87:881-92.

53 Barbosa V, Sievers RE, Zaugg CE, et al. Preconditioning ischemia time determines the degree of glycogen depletion and infarct size reduction in rat hearts. Am Heart J 1996;131:224-30.

54 Muller DW, Topol EJ, Califf RM, et al. Relationship between anteceden angina pectoris and short-term prognosis after thrombolytic therapy for acute myocardial infarction. Thrombolysis and angioplasty in myocardial infarction (TAMI) study group. Am Heart J 1990;1 19:224-31.

55 Deutsch E, Berger M, Kussmaul WG, et al. Adaptation to ischemia during percutaneous transluminal coronary angioplasty. Clinical, hemodynamic, and metabolic features. Circulation 1990;82:2044-51.

56 Yellon DM, Alkhulaifi AM, Pugsley WB. Preconditioning the human myocardium. Lancet 1993;342:276-7.

57 Ottani F, Galvani M, Ferrini D, et al. Prodromal angina limits infarct size. A role for ischemic preconditioning. Circulation 1995;91:291-7.

$58 \mathrm{Li}$ Y, Kloner RA. Does protein kinase $C$ play a role in ischemic preconditioning in rat hearts? Am J Physiol 1995;268:H426-31.

59 Takashi E, Wang Y, Ashraf M. Activation of mitochondrial K(ATP) channel elicits late preconditioning against myocardial infarction via protein kinase C signaling pathway. Circ Res 1999;85: 1146-53.

60 Li WG, Zaheer A, Coppey L, et al. Activation of JNK in the remote myocardium after large myocardial infarction in rats. Biochem Biophys Res Commun 1998;246:816-20.

61 Oskarsson HJ, Coppey L, Weiss RM, Li WG. Antioxidants attenuate myocyte apoptosis in the remote non-infarcted myocardium following large myocardial infarction. Cardiovasc Res 2000;45:679-87.

62 Miyashita T, Krajewski S, Krajewska M, et al. Tumor suppressor p53 is a regulator of bcl-2 and bax gene expression in vitro and in vivo. Oncogene 1994; 9: 1799-805.

63 Fujio Y, Kunisada K, Hirota H, et al. Signals through gp 130 upregulate bcl-x gene expression via STAT1-binding cis-element in cardiac myocytes. J Clin Invest 1997:99:2898-905.

64 Negoro S, Oh H, Tone E, et al. Glycoprotein 130 regulates cardiac myocyte survival in doxorubicin-induced apoptosis through phosphatidylinositol 3-kinase/Akt phosphorylation and Bcl-xL/caspase-3 interaction. Circulation 2001;103:555-61.

65 Negoro S, Kunisada K, Tone E, et al. Activation of JAK/STAT pathway transduces cytoprotective signal in rat acute myocardial infarction. Cardiovasc Res 2000;47:797-805.

66 Kyriakis JM, Banerjee P, Nikolakaki E, et al. The stress-activated protein kinase subfamily of c-Jun kinases. Nature 1994;369:156-60.

67 Yin T, Sandhu G, Wolfgang CD, et al. Tissue-specific pattern of stress kinase activation in ischemic/reperfused heart and kidney. J Biol Chem 1997;272: 19943-50.

68 Buerke M, Murohara T, Skurk C, et al. Cardioprotective effect of insulin-like growth factor I in myocardial ischemia followed by reperfusion. Proc Natl Acad Sci U S A 1995:92:8031-5.

69 Li Q, Li B, Wang X, et al. Overexpression of insulin-like growth factor-1 in mice protects from myocyte death after infarction, attenuating ventricular dilation, wall stress, and cardiac hypertrophy. J Clin Invest 1997; 100:1991-9.

70 Haylor J, Singh I, el Nahas AM. Nitric oxide synthesis inhibitor prevents vasodilation by insulin-like growth factor I. Kidney Int 1991;39:333-5.

71 Tsukahara H, Gordienko DV, Tonshoff B, et al. Direct demonstration of insulin-like growth factor-l-induced nitric oxide production by endothelial cells. Kidney Int 1994;45:598-604.

72 Weiland U, Haendeler J, Ihling C, et al. Inhibition of endogenous nitric oxide synthase potentiates ischemia-reperfusion-induced myocardial apoptosis via a caspase-3 dependent pathway. Cardiovasc Res 2000;45:671-8

73 Ang D, Liberek K, Skowyra D, et al. Biological role and regulation of the universally conserved heat shock proteins. J Biol Chem 1991;266:24233-6

74 Suzuki K, Sawa Y, Kagisaki K, et al. Reduction in myocardial apoptosis associated with overexpression of heat shock protein 70. Basic Res Cardiol 2000;95:397-403.

75 De Windt LJ, Lim HW, Taigen T, et al. Calcineurin-mediated hypertrophy protects cardiomyocytes from apoptosis in vitro and in vivo: an apoptosis-independent model of dilated heart failure Circ Res 2000;86:255-63.

76 Herskowitz A, Choi S, Ansari AA, et al. Cyłokine mRNA expression in postischemic/reperfused myocardium. Am J Pathol 1995;146:419-28.

77 Gwechenberger M, Mendoza LH, Youker KA, et al. Cardiac myocytes produce interleukin- 6 in culture and in viable border zone of reperfused infarctions. Circulation 1999;99:546-51.

78 Mann DL. Stress activated cytokines and the heart. Cytokine Growth Factor Rev 1996;7:341-54.

79 Beg AA, Baltimore D. An essential role for NF-kappaB in preventing TNF-alpha-induced cell death. Science 1996:274:782-4.

80 Kurrelmeyer KM, Michael LH, Baumgarten G, et al. Endogenous tumor necrosis factor protects the adult cardiac myocyte against ischemic-induced apoptosis in a murine model of acute myocardial infarction. Proc Natl Acad Sci U S A 2000;97:5456-61.

81 Shimizu S, Eguchi Y, Kamiike W, et al. Bcl-2 blocks loss of mitochondrial membrane potential while ICE inhibitors act at a different step during inhibition of death induced by respiratory chain inhibitors. Oncogene 1996;13:21-9.

82 Shimizu S, Eguchi Y, Kamiike W, et al. Retardation of chemical hypoxia-induced necrotic cell death by Bcl-2 and ICE inhibitors: possible involvement of common mediators in apoptotic and necrotic signal transductions. Oncogene 1996;1 2:2045-50.

83 Okamura T, Miura T, Takemura G, et al. Effect of caspase inhibitors on myocardial infarct size and myocyte DNA fragmentation in the ischemia-reperfused rat heart. Cardiovasc Res 2000;45:642-50.

84 Condorelli G, Roncarati R, Ross J Jr, et al. Heart-targeted overexpression of caspase 3 in mice increases infarct size and depresses cardiac function. Proc Natl Acad Sci U S A 2001;98:9977-82.

85 Yoshida H, Zhang JJ, Chao L, et al. Kallikrein gene delivery attenuates myocardial infarction and apoptosis after myocardial ischemia and reperfusion. Hypertension 2000;35:25-31.

86 Xiong W, Chen LM, Woodley-Miller C, et al. Identification, purification, and localization of tissue kallikrein in rat heart. Biochem J 1990;267:639-46

87 Nolly H, Carbini LA, Scicli G, et al. A local kallikrein-kinin system is present in rat hearts. Hypertension 1994;23:919-23.

88 Hess JF, Borkowski JA, Young GS, et al. Cloning and pharmacological characterization of a human bradykinin (BK-2) receptor. Biochem Biophys Res Commun 1992;184:260-8.

89 Azhar G, Gao W, Liu L, et al. Ischemia-reperfusion in the adult mouse heart influence of age. Exp Gerontol 1999:34:699-714.

90 Liu L, Azhar G, Gao W, et al. Bcl-2 and Bax expression in adult rat hearts after coronary occlusion: age-associated differences. Am J Physiol 1998;275:R315-22.

91 Maulik N, Engelman RM, Rousou JA, et al. Ischemic preconditioning reduces apoptosis by upregulating anti-death gene $\mathrm{Bcl}-2$. Circulation 1999; 100:॥369-75.

92 Hattori $\mathbf{R}$, Hernandez TE, Zhu L, et al. An essential role of the antioxidant gene $\mathrm{Bcl}-2$ in myocardial adaptation to ischemia: an insight with antisense $\mathrm{Bcl}-2$ therapy. Antioxidants and Redox Signalling 2001;3:403-13

93 Mascareno E, El Shafei M, Maulik N, et al. JAK/STAT signaling is associated with cardiac dysfunction during ischemia and reperfusion. Circulation 2001;104:325-9.

94 Au-Yeung KK, Zhu DY, O K, et al, Inhibition of stress-activated protein kinase in the ischemic/reperfused heart: role of magnesium tanshinoate $B$ in preventing apoptosis. Biochem Pharmacol 2001;62:483-93.

95 Bogoyevitch MA, Gillespie-Brown J, Ketterman AJ, et al. Stimulation of the stress-activated mitogen-activated protein kinase subfamilies in perfused heart. p38/RK mitogen-activated protein kinases and c-Jun $\mathrm{N}$-terminal kinases are activated by ischemia/reperfusion. Circ Res 1996;79:162-73

96 Pombo CM, Bonventre JV, Avruch J, et al. The stress-activated protein kinases are major c-Jun amino-terminal kinases activated by ischemia and reperfusion. J Biol Chem 1994;269:26546-51.

97 Yue TL, Wang C, Gu JL, et al. Inhibition of extracellular signal-regulated kinase enhances ischemia/reoxygenation-induced apoptosis in cultured cardiac myocytes and exaggerates reperfusion injury in isolated perfused heart. Circ Res 2000;86:692-9.

98 Qian YZ, Bernardo NL, Nayeem MA, et al. Induction of 72-kDa heat shock protein does not produce second window of ischemic preconditioning in rat heart. Am J Physiol 1999;276:H224-34

99 Sage MD, Jennings RB. Cytoskeletal injury and subsarcolemmal bleb formation in dog heart during in vitro total ischemia. Am J Pathol 1988; 133:327-37

100 Martin JL, Mestril R, Hilal-Dandan R, et al. Small heat shock proteins and protection against ischemic injury in cardiac myocytes. Circulation 1997;96:4343-8

101 Ray PS, Martin JL, Swanson EA, et al. Transgene overexpression of alphaB crystallin confers simultaneous protection against cardiomyocyte apoptosis and necrosis during myocardial ischemia and reperfusion. FASEB J 2001;15:393-402

102 Borutaite V, Budriunaite A, Morkuniene R, et al. Release of mitochondrial cytochrome $c$ and activation of cytosolic caspases induced by myocardial ischaemia. Biochim Biophys Acta 2001;1537:101-9.

103 Malhotra R, Brosius FC III. Glucose uptake and glycolysis reduce hypoxia-induced apoptosis in cultured neonatal rat cardiac myocytes. Biol Chem 1999;274:12567-75.

104 Bialik S, Cryns VL, Drincic A, et al. The mitochondrial apoptotic pathway is activated by serum and glucose deprivation in cardiac myocytes. Circ Res 1999;85:403-14. 
105 Narayan P, Mentzer RM Jr, Lasley RD. Annexin V staining during reperfusion detects cardiomyocytes with unique properties. Am J Physiol 2001;281:H1931-7

106 Tanaka M, Ito H, Adachi S, et al. Hypoxia induces apoptosis with enhanced expression of Fas antigen messenger RNA in cultured neonatal rat cardiomyocytes. Circ Res 1994;75:426-33.

107 Stephanou A, Scarabelli TM, Brar BK, et al. Induction of apoptosis and Fas receptor/Fas ligand expression by ischemia/reperfusion in cardiac myocytes requires serine 727 of the STAT-1 transcription factor but not tyrosine 701. J Biol Chem 2001;276:28340-7.

108 von Harsdorf R, Li PF, Dietz R. Signaling pathways in reactive oxygen species-induced cardiomyocyte apoptosis. Circulation 1999;99:2934-41

109 Akao M, Ohler A, O'Rourke B, et al. Mitochondrial ATP-sensitive potassium channels inhibit apoptosis induced by oxidative stress in cardiac cells. Circ Res 2001;88:1267-75.

110 Takahashi A, Alnemri ES, Lazebnik YA, et al. Cleavage of lamin A by Mch2 alpha but not CPP32: multiple interleukin 1 beta-converting enzyme-related proteases with distinct substrate recognition properties are active in apoptosis. Proc Natl Acad Sci U S A 1996:93:8395-400.

111 Shen JG, Quo XS, Jiang B, et al. Chinonin, a novel drug against cardiomyocyte apoptosis induced by hypoxia and reoxygenation. Biochim Biophys Acta 2000;1500:217-26.

112 Long X, Boluyt MO, Hipolito ML, et al. p53 and the hypoxia-induced apoptosis of cultured neonatal rat cardiac myocytes. J Clin Invest 1997;99:2635-43.

113 Mackay K, Mochly-Rosen D. An inhibitor of p38 mitogen-activated protein kinase protects neonatal cardiac myocytes from ischemia. J Biol Chem 1999:274:6272-9.

114 Minamino T, Yujiri T, Papst PJ, et al. MEKK 1 suppresses oxidative stress-induced apoptosis of embryonic stem cell-derived cardiac myocytes. Proc Natl Acad Sci U S A 1999;96:15127-32.

115 Mizukami Y, Okamura T, Miura T, et al. Phosphorylation of proteins and apoptosis induced by c-Jun $\mathrm{N}$-terminal kinase l activation in rat cardiomyocytes by $\mathrm{H}(2) \mathrm{O}(2)$ stimulation. Biochim Biophys Acta 2001;1540:213-20.

116 Kitta K, Day RM, lkeda T, et al. Hepatocyte growth factor protects cardiac myocytes against oxidative stress-induced apoptosis. Free Radic Biol Med 2001;31:902-10.

117 Adderley SR, Fitzgerald DJ. Oxidative damage of cardiomyocytes is limited by extracellular regulated kinases 1/2-mediated induction of cyclooxygenase-2. J Biol Chem 1999;274:5038-46

118 Matsui T, Li L, del Monte F, et al. Adenoviral gene transfer of activated phosphatidylinositol 3'-kinase and Akt inhibits apoptosis of hypoxic cardiomyocytes in vitro. Circulation 1999;100:2373-9.

119 Mehrhof FB, Muller FU, Bergmann MW, et al. In cardiomyocyte hypoxia, insulin-like growth factor-l-induced antiapoptotic signaling requires phosphatidylinositol-3-OH-kinase- dependent and mitogen-activated protein kinase-dependent activation of the transcription factor cAMP response element-binding protein. Circulation 2001;104:2088-94.

120 Mosser DD, Caron AW, Bourget L, et al. Role of the human heat shock protein hsp70 in protection against stress-induced apoptosis. Mol Cell Biol 1997:17:5317-27.
121 Brar BK, Stephanou A, Wagstaff M, et al. Heat shock proteins delivered with a virus vector can protect cardiac cells against apoptosis as well as against thermal or hypoxic stress. J Mol Cell Cardiol 1999;31:135-46.

122 Dix DJ, Allen JW, Collins BW, et al. Targeted gene disruption of Hsp70-2 results in failed meiosis, germ cell apoptosis, and male infertility. Proc Natl Acad Sci U S A 1996;93:3264-8

123 Kakita T, Hasegawa K, Iwai-Kanai E, et al. Calcineurin pathway is required for endothelin-1-mediated protection against oxidant stress-induced apoptosis in cardiac myocytes. Circ Res 2001;88: 1239-46.

124 Krown KA, Page MT, Nguyen C, et al. Tumor necrosis factor alpha-induced apoptosis in cardiac myocytes. Involvement of the sphingolipid signaling cascade in cardiac cell death. J Clin Invest 1996;98:2854-65.

125 Bergmann MW, Loser P, Dietz R, et al. Effect of NF-kappa B inhibition on TNF-alpha-induced apoptosis and downstream pathways in cardiomyocytes. J Mol Cell Cardiol 2001;33:1223-32.

126 Saraste A. Morphologic criteria and detection of apoptosis. Herz 1999;24:189-95

127 Ohno M, Takemura G, Ohno A, et al. "Apoptotic" myocytes in infarct area in rabbit hearts may be oncotic myocytes with DNA fragmentation: analysis by immunogold electron microscopy combined with in situ nick end-labeling. Circulation 1998;98:1422-30.

128 Darzynkiewicz Z, Bruno S, Del Bino G, et al. Features of apoptotic cells measured by flow cytometry. Cytometry 1992;13:795-808

129 Gerschenson LE, Rotello RJ. Apoptosis: a different type of cell death. FASEB J 1992;6:2450-5.

130 Wyllie AH, Morris RG, Smith AL, et al. Chromatin cleavage in apoptosis: association with condensed chromatin morphology and dependence on macromolecular synthesis. J Pathol 1984;142:67-77

131 Blankenberg FG, Strauss HW. Will imaging of apoptosis play a role in clinical care? A tale of mice and men. Apoptosis 2001/6:117-23.

132 van Heerde WL, Robert-Offerman S, Dumont E, et al. Markers of apoptosis in cardiovascular tissues: focus on annexin V. Cardiovasc Res 2000;45:549-59.

133 Entman ML, Michael L, Rossen RD, et al. Inflammation in the course of early myocardial ischemia. FASEB J 1991;5:2529-37.

134 Smith CW, Entman ML, Lane CL, et al. Adherence of neutrophils to canine cardiac myocytes in vitro is dependent on intercellular adhesion molecule-1. J Clin Invest 1991:88:1216-23.

135 Kukielka GL, Hawkins HK, Michael L, et al. Regulation of intercellular adhesion molecule-1 (ICAM-1) in ischemic and reperfused canine myocardium. J Clin Invest 1993;92:1504-16.

136 Youker K, Smith CW, Anderson DC, et al. Neutrophil adherence to isolated adult cardiac myocytes. Induction by cardiac lymph collected during ischemia and reperfusion. J Clin Invest 1992;89:602-9.

137 Lieberthal W, Menza SA, Levine JS. Graded ATP depletion can cause necrosis or apoptosis of cultured mouse proximal tubular cells. Am J Physiol 1998;274:F315-27.

138 Shiraishi J, Tatsumi T, Keira N, et al. Important role of energy-dependent mitochondrial pathways in cultured rat cardiac myocyte apoptosis. Am J Physiol 2001;281:H1637-47. 